ORIGINAL ARTICLE

\title{
Photographic Profile Analysis in Preschool Children of Thiruvananthapuram, Kerala
}

\author{
Bhawna Gautam¹, Sheela Sreedharan², Suchithra M Seetha ${ }^{3}$
}

\begin{abstract}
Aim: The purpose of the study is to establish baseline normative data regarding facial soft tissue profile measurements in preschool children of Thiruvananthapuram.

Materials and methods: The present study was a cross-sectional study conducted at the Department of Pedodontics, Government Dental College, Thiruvanthapuram. Two hundred fifty children of 3 to 5 years of age reporting at the outpatient department with complete primary dentition and flush terminal plane molar relation were the sampling unit. Children with mixed dentition, with the a presence of proximal caries and any oral habit and maxillofacial trauma/pathology/developmental defects, were not included in the study. The level of significance for the study was set as $p<0.05$.

Results: Mean values of the study variable with standard deviation obtained with a narrow range of $95 \%$ the confidence interval indicated higher accuracy of the study.

Conclusion: The values obtained in the study can be used as a reference for an initial orthodontic evaluation of a child during the early mixed dentition period. The study will help in predicting the direction of growth of the dentofacial region, its effect on facial parameters, and, hence, the treatment plan can be modified accordingly. The study will serve as the reference study for further studies with molar plane relation other than FTP.
\end{abstract}

Keywords: Facial profile analysis, FTP molar relation, Photographic analysis, Preschool children.

International Journal of Clinical Pediatric Dentistry (2019): 10.5005/jp-journals-10005-1605

\section{INTRODUCTION}

In orthodontics, pretreatment soft-tissue analysis has always been used to determine facial esthetics, thus, offering an important tool to clinicians. ' Classical, quantitative assessments of soft-tissue profiles have been performed by using lateral skull radiographs ${ }^{2}$ and several cephalometric analyses have been developed and proposed.

The introduction of radiographic analyses, and the subsequent cephalometric assessments, made facial photography, a passive record for several years. The emphasis was on the objective assessment of cephalometric radiographs, leaving only a subjective role for lateral photographs. Photographs have been widely used for the identification of an esthetic ideal. ${ }^{3-5}$ More recently, radioprotection concerns made researchers rediscover photography. The method was first used to describe the soft-tissue profile of children with unilateral cleft lip and palate by using linear and angular measurements from profile photographs. ${ }^{6,7}$ With the advent of advanced photographic techniques, it is possible to capture facial photographs with minimal distortion.

Several studies have assessed the soft tissues from adolescence to adulthood with lateral photographs. ${ }^{8-10}$ Quantitative photographic analyses of the soft-tissue profile were used to measure the influence of the various classes of malocclusion in adults ${ }^{8}$ and, in particular, they were used to measure the influence of orthodontic treatment on facial esthetics. ${ }^{11}$ The literature includes very few data on profile analysis in children. ${ }^{12-16}$

In general, facial profile evaluation in children is more difficult than in adults because of the underlying dynamic skeletal growth taking place, but it is a primary area of concern starting at the early mixed dentition period. ${ }^{17}$ From a clinical point of view, it is often too early to begin a treatment, but the quantification of the soft-tissue
${ }^{1-3}$ Department of Pedodontics and Preventive Dentistry, Government
Dental College, Thiruvananthapuram, Kerala, India
Corresponding Author:Bhawna Gautam, Department of Pedodontics and
Preventive Dentistry, Government Dental College, Thiruvananthapuram,
Kerala, India, Phone: +918860028949, e-mail: dr.bhawna.vasundhara@
gmail.com

How to cite this article: Gautam B, Sreedharan S, et al. Photographic Profile Analysis in Preschool Children of Thiruvananthapuram, Kerala. Int J Clin Pediatr Dent 2019;12(2):111-115.

Source of support: Nil

Conflict of interest: None

profile at this age could be useful from a prognostic and diagnostic point of view.

The aims of this study are twofold: to develop a simple and fast method for the quantification of the soft-tissue profile by a lateral photograph and to collect data on normal, healthy children aged 3-5 years of both genders with flush terminal plane molar relation. The definition of normal values could be of interest in the clinical assessment of orthodontic patients.

\section{Materials and Methods}

The cross-sectional study was conducted at the Department of Pedodontics and Preventive Dentistry, Government Dental College, Thiruvananthapuram. Children of 3-5 years of age reporting at the outpatient department with complete primary dentition and flush terminal plane molar plane relation were the sampling unit. Children with mixed dentition, with the presence of proximal

(C) The Author(s). 2019 Open Access This article is distributed under the terms of the Creative Commons Attribution 4.0 International License (https://creativecommons. org/licenses/by-nc/4.0/), which permits unrestricted use, distribution, and non-commercial reproduction in any medium, provided you give appropriate credit to the original author(s) and the source, provide a link to the Creative Commons license, and indicate if changes were made. The Creative Commons Public Domain Dedication waiver (http://creativecommons.org/publicdomain/zero/1.0/) applies to the data made available in this article, unless otherwise stated. 
caries and any oral habit and maxillofacial trauma/pathology/ developmental defects, were not included in the study. The sample size was estimated to be 250 .

\section{Photographic Set up}

Photographic set up consisted of a Nikon DSLR Camera with 18 to $55 \mathrm{~mm}$ macro lens having a primary flash. A tripod stand was used as a leveling unit to maintain the correct horizontal positioning of the optical lens.

\section{Record Taking}

The photographs were taken in a natural head position. According to Lundström, ${ }^{18}$ the normal head posture is defined as the mean position of the head when the individual is standing in a relaxed position with the visual axis horizontal.

Following measurements were recorded:

- Profile angle: Gla'-Sn-Pg' soft tissue glabella-subnasale-soft tissue pogonion (Fig. 1).

- Nasolabial angle: C-Sn-ULA columella-subnasale-upper lip anterior (Fig. 2).

- Nasofrontal angle: formed by drawing a line tangent to Glabella through the Nasion that will intersect a line drawn a tangent to the nasal dorsum (Fig. 3).

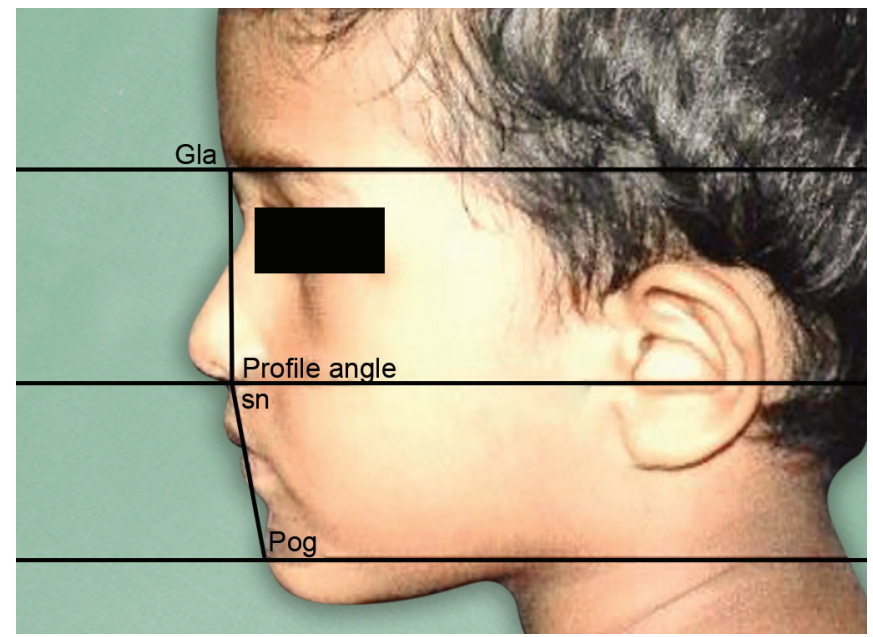

Fig. 1: Profile angle

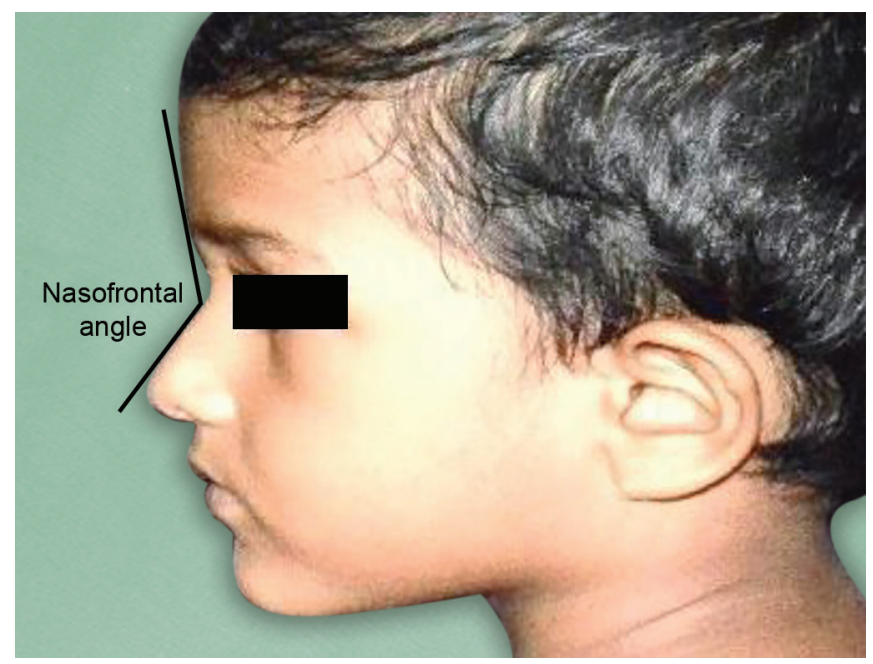

Fig. 3: Nasofrontal angle
- Nasofacial angle: it is formed by drawing a vertical line tangent to the forehead at the glabella and the tangent to the chin at the pogon-ion so that a line drawn along the nasal dorsum intersects it (Fig. 4).

- Nasomental angle: it is formed by the line drawn through the nasal dorsum intersecting a line drawn from nasal tip to soft tissue chin at pogonion (Fig. 5).

- Mentocervical angle: a vertical line tangent to the forehead passing at glabella and second line intersecting tangent to the chin at pogonion (Fig. 6).

- Maxillary sulcus contour (mm) (Fig. 7).

- Mandibular sulcus contour (mm) (Fig. 8).

- Throat length $(\mathrm{mm})$ : neck throat point to soft tissue menton (TL = NTP-Me (Fig. 9)).

- Subnasale-pogonion ( $\mathrm{mm}$ ): Sn-Pog' lip projections are evaluated relative to this line (Fig. 10).

\section{Results}

Mean values of the study variable with standard deviation obtained with a narrow range of $95 \%$ confidence interval indicating higher accuracy of the study (Table 1). The profile angle differs between boys and girls with a $p$ value of $<0.05$ (Table 2). Nasolabial angle, nasofrontal angle, nasofacial angle, nasomental angle, and

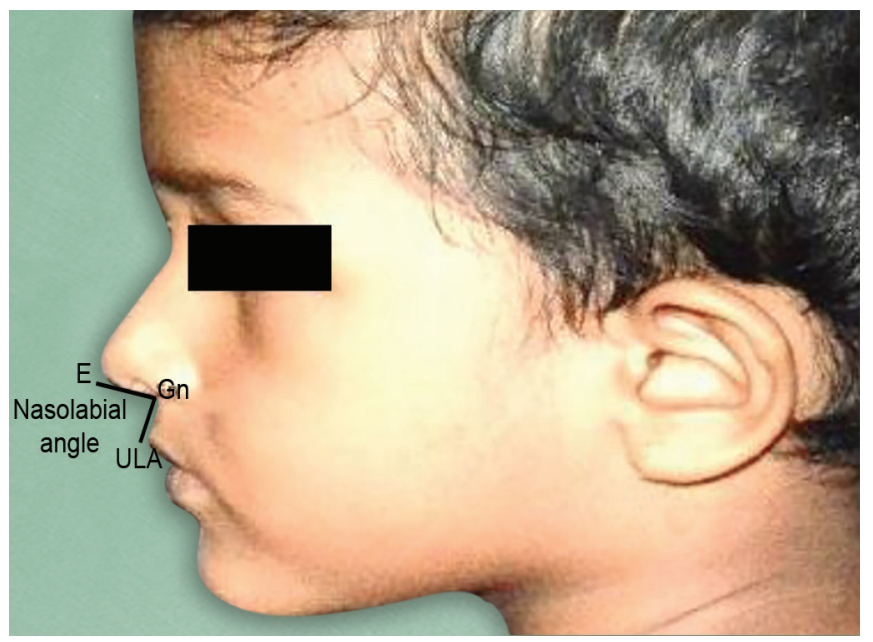

Fig. 2: Nasolabial angle

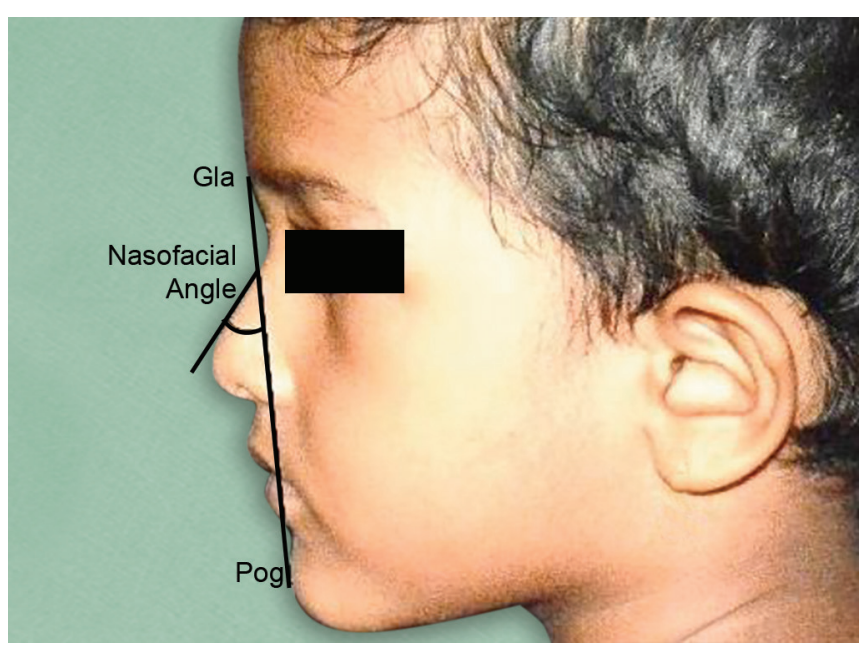

Fig. 4: Nasofacial angle 


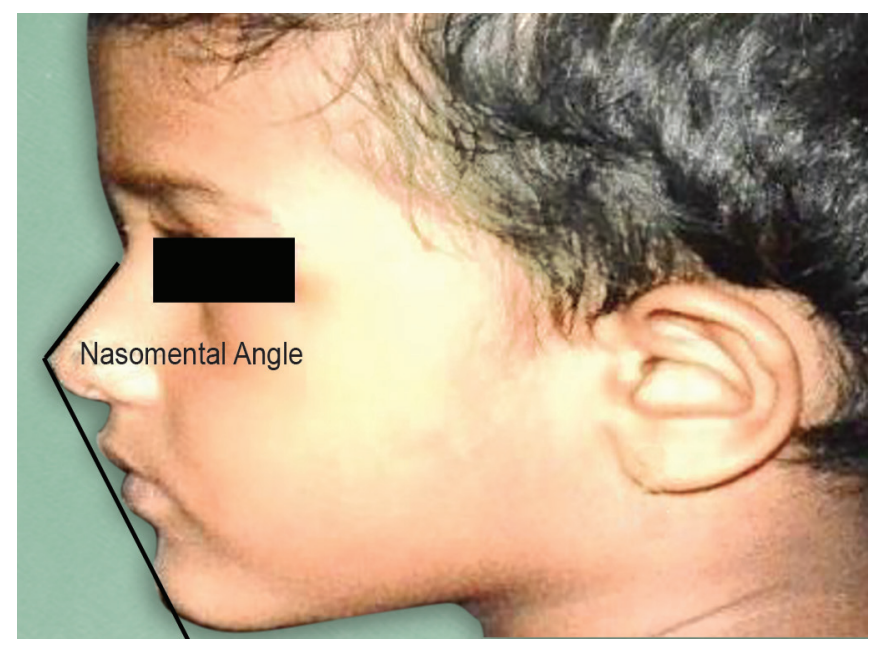

Fig. 5: Nasomental angle

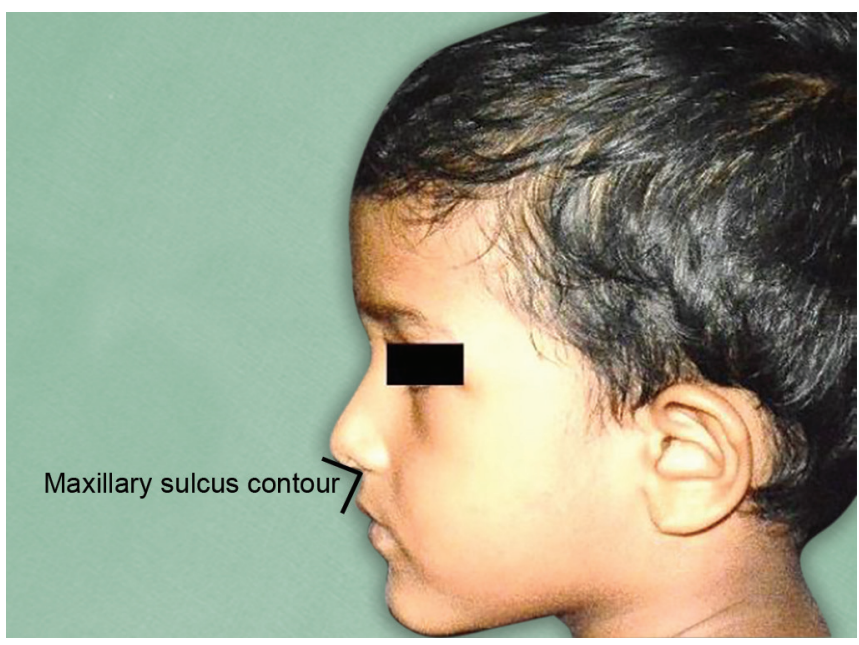

Fig. 7: Maxillary sulcus contour

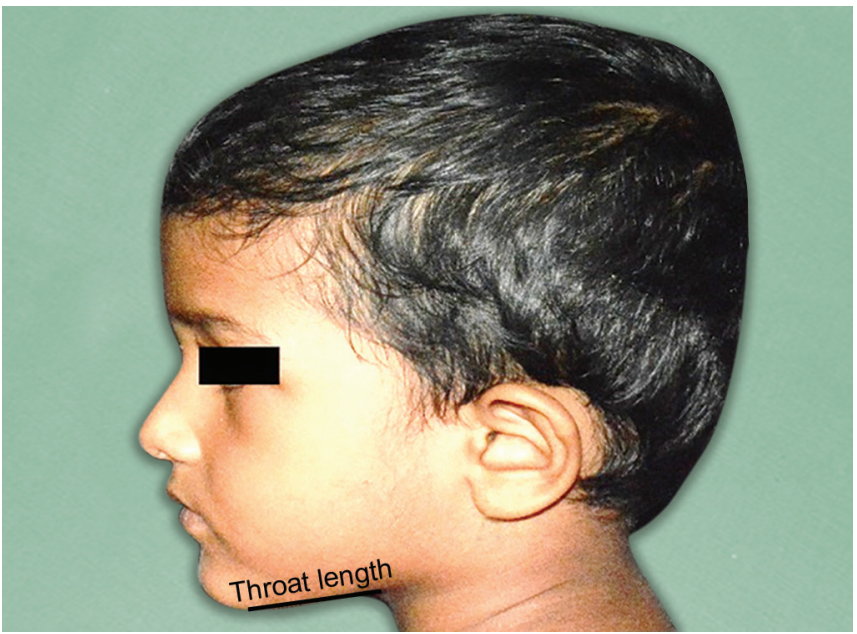

Fig. 9: Throat length

mentocervical angle did not differ between boys and girls with a $p$ value of $>0.05$ for all the angles (Table 2). Nasofrontal angle, nasofacial angle, nasomental angle, and mentocervical angle showed a significant correlation with the age ( $p$ value $<0.05$ ), whereas profile angle and nasolabial angle did not show any significant correlation with the age (Table 3 ).

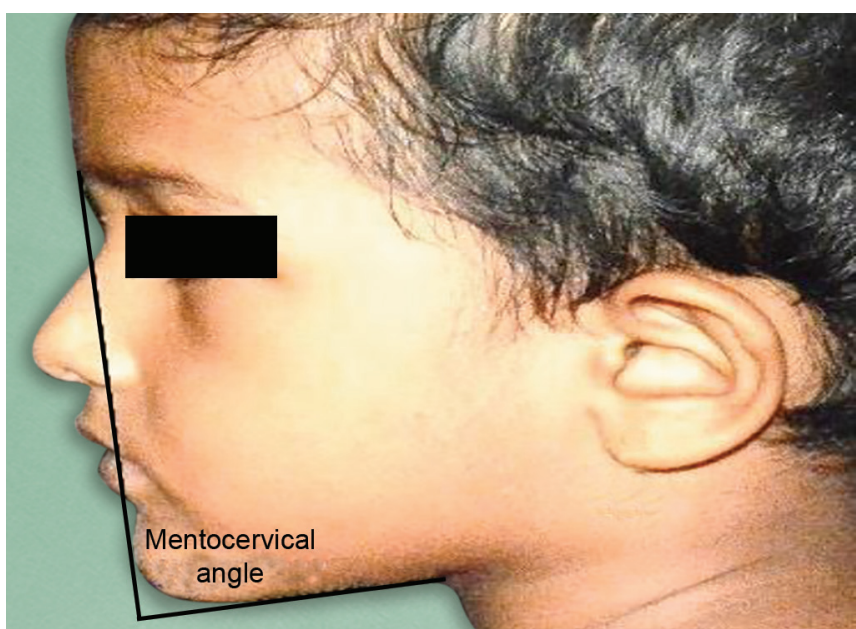

Fig. 6: Mentocervical angle

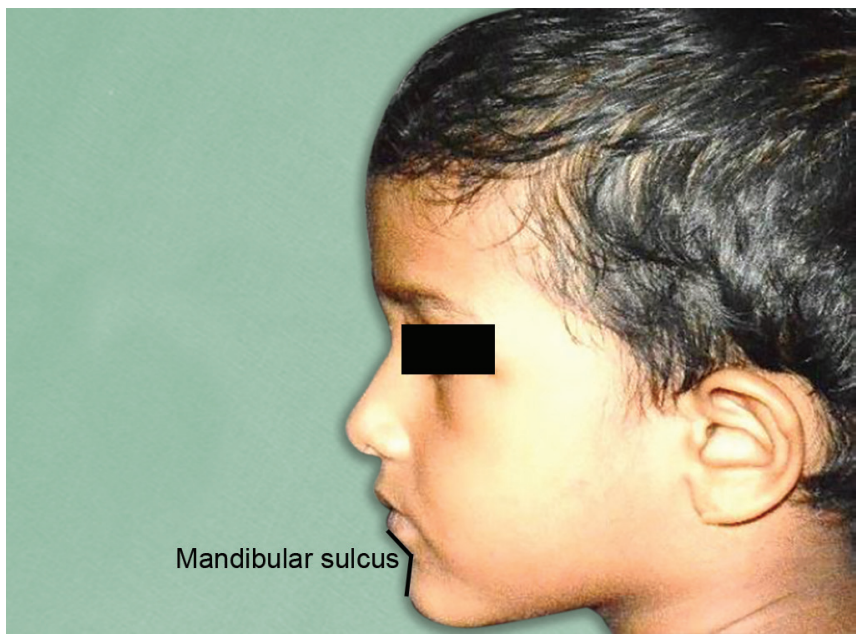

Fig. 8: Mandibular sulcus contour

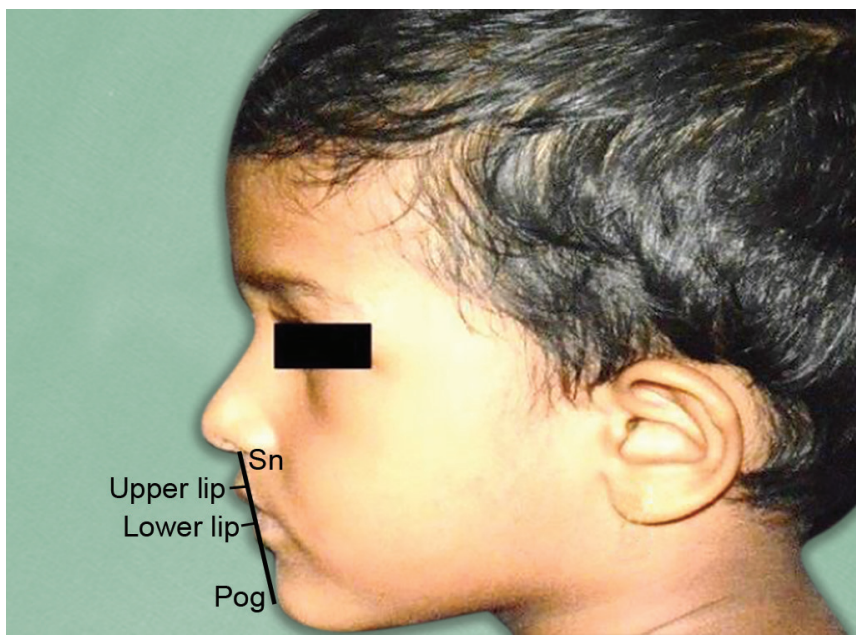

Fig. 10: Upper and lower lip projections

\section{Discussion and Conclusion}

The present study provides a comprehensive facial profile analysis in 3-5 year-old-children. The measurements used in the study were intended to provide a baseline values or the normal values for the given range of age. These values will aid in apt diagnosis 
Photographic Profile Analysis in Preschool Children of Thiruvananthapuram, Kerala

Table 1: Correlation of study variables with age

\begin{tabular}{llll}
\hline Relationship & Correlation & p value & Significance \\
\hline Profile angle $\left(^{\circ}\right)$ & 0.014 & 0.820 & $\mathrm{NS}$ \\
Nasolabial angle $\left(^{\circ}\right)$ & 0.103 & 0.104 & $\mathrm{NS}$ \\
Nasofrontal angle $\left(^{\circ}\right)$ & 0.149 & 0.019 & $\mathrm{~S}$ \\
Nasofacial angle $\left(^{\circ}\right)$ & 0.225 & 0.000 & $\mathrm{~S}$ \\
Nasomental angle $\left(^{\circ}\right)$ & 0.187 & 0.003 & $\mathrm{~S}$ \\
Mentocervical angle $\left(^{\circ}\right)$ & 0.226 & 0.000 & $\mathrm{~S}$ \\
Maxillary sulcus contour (mm) & 0.018 & 0.775 & $\mathrm{NS}$ \\
Mandibular sulcus contour & 0.124 & 0.051 & $\mathrm{~S}$ \\
(mm) & & & \\
Throat length (mm) & 0.047 & 0.461 & $\mathrm{NS}$ \\
Upper lip to Sn-Pog (mm) & 0.092 & 0.150 & $\mathrm{NS}$ \\
Lower lip to Sn-Pog (mm) & 0.117 & 0.067 & $\mathrm{NS}$ \\
\hline S, signicant; , non-signifcant & & &
\end{tabular}

S, significant; NS, non-significant

Table 2: Mean value of study variables genderwise

\begin{tabular}{|c|c|c|c|c|}
\hline Variable & Gender & Mean & $S D$ & Significance \\
\hline \multirow[t]{2}{*}{ Profile angle $\left({ }^{\circ}\right)$} & Male & 162.686 & 6.588 & $\mathrm{~S}$ \\
\hline & Female & 164.436 & 4.180 & \\
\hline \multirow[t]{2}{*}{ Nasolabial angle $\left(^{\circ}\right)$} & Male & 103.966 & 10.481 & NS \\
\hline & Female & 102.391 & 10.462 & \\
\hline \multirow[t]{2}{*}{ Nasofrontal angle $\left({ }^{\circ}\right)$} & Male & 135.883 & 11.978 & NS \\
\hline & Female & 135.991 & 5.791 & \\
\hline \multirow[t]{2}{*}{ Nasofacial angle $\left({ }^{\circ}\right)$} & Male & 43.364 & 5.293 & NS \\
\hline & Female & 42.920 & 4.303 & \\
\hline \multirow[t]{2}{*}{ Nasomental angle $\left({ }^{\circ}\right)$} & Male & 119.478 & 5.165 & NS \\
\hline & Female & 119.057 & 5.361 & \\
\hline \multirow[t]{2}{*}{ Mentocervical angle $\left({ }^{\circ}\right)$} & Male & 93.90 & 7.54 & NS \\
\hline & Female & 93.99 & 5.92 & \\
\hline \multirow{2}{*}{$\begin{array}{l}\text { Maxillary sulcus contour } \\
(\mathrm{mm})\end{array}$} & Male & 4.547 & 1.062 & NS \\
\hline & Female & 4.561 & 1.081 & \\
\hline \multirow{2}{*}{$\begin{array}{l}\text { Mandibular sulcus contour } \\
(\mathrm{mm})\end{array}$} & Male & 5.302 & 1.122 & NS \\
\hline & Female & 5.203 & 1.073 & \\
\hline \multirow[t]{2}{*}{ Throat length (mm) } & Male & 35.29 & 4.70 & NS \\
\hline & Female & 36.28 & 5.01 & \\
\hline \multirow[t]{2}{*}{ Upper lip to Sn-Pog (mm) } & Male & 6.368 & 1.982 & $S$ \\
\hline & Female & 5.504 & 1.995 & \\
\hline \multirow[t]{2}{*}{ Lower lip to Sn-Pog (mm) } & Male & 4.63 & 1.93 & $S$ \\
\hline & Female & 4.11 & 1.98 & \\
\hline
\end{tabular}

S, significant; NS, non-significant. $p$ value $<0.05$

and treatment planning. Pediatric dentists encounter a child de novo and, hence, having knowledge of normal values would aid in comprehensive diagnosis and treatment planning for skeletal problems, which will go a long way. If not dealt properly, may lead to further exacerbation of the dental/skeletal problem.

The present study provides a set of values of different facial dimensions which could be considered as ideal/normal for the given range of children age, the deviation from which would obviate preventive and interceptive treatment planning. The measurements included in the study are important parameters for facial analysis which should be considered for an orthodontic evaluation, diagnosis, and treatment planning.

The application of photographic analysis in daily clinical practice is an easy, simple, and inexpensive method. There is no risk of
Table 3: Correlation of study variables with age

\begin{tabular}{llll}
\hline Relationship & Correlation & p value & Significance \\
\hline Profile angle $\left(^{\circ}\right)$ & 0.014 & 0.820 & $\mathrm{NS}$ \\
Nasolabial angle $\left(^{\circ}\right)$ & 0.103 & 0.104 & $\mathrm{NS}$ \\
Nasofrontal angle $\left(^{\circ}\right)$ & 0.149 & 0.019 & $\mathrm{~S}$ \\
Nasofacial angle $\left(^{\circ}\right)$ & 0.225 & 0.000 & $\mathrm{~S}$ \\
Nasomental angle $\left(^{\circ}\right)$ & 0.187 & 0.003 & $\mathrm{~S}$ \\
Mentocervical angle $\left(^{\circ}\right)$ & 0.226 & 0.000 & $\mathrm{~S}$ \\
Maxillary sulcus contour $(\mathrm{mm})$ & 0.018 & 0.775 & $\mathrm{NS}$ \\
Mandibular sulcus & 0.124 & 0.051 & $\mathrm{~S}$ \\
contour (mm) & & & \\
Throat length (mm) & 0.047 & 0.461 & $\mathrm{NS}$ \\
Upper lip to Sn-Pog (mm) & 0.092 & 0.150 & $\mathrm{NS}$ \\
Lower lip to Sn-Pog (mm) & 0.117 & 0.067 & $\mathrm{NS}$ \\
\hline S, signifcant NS, non-signfcant & & &
\end{tabular}

S, significant; NS, non-significant

radiation exposure to the children during the crucial growing period. The photographic system being familiar to the public is better accepted by the parents and the children.

For an accurate prediction of dentofacial growth and development, further longitudinal studies are required. The longitudinal study on the study population could be continued wherein the influence of genetic makeup, environmental exposures, and other unmeasured characteristics that tend to persist over time can be evaluated. Longitudinal quantitative evaluation of soft tissue facial dimensions will also inform the clinician about the growth and treatment changes. In the present study, only flush terminal plane molar relationship of primary dentition was included, further studies involving mesial step and distal step terminal plane molar relation may be conducted for the comparative evaluation of facial morphometry on basis of molar relation.

\section{References}

1. Peck S, Peck L. Selected aspects of the art and science of facial esthetics. Semin Orthod 1995;1:105-126. DOI: 10.1016/S10738746(95)80097-2.

2. Broadbent $\mathrm{Sr} \mathrm{BH}$, Broadbent Jr BH, et al. Boltonm standards of dentofacial developmental growth. St. Louis: C.V. Mosby; 1975.

3. Al Yami EA, Kuijpers-Jagtman AM, et al. Assessment of dental and facial aesthetics in adolescents. Eur J Orthod 1998;20:399-405. DOI: 10.1093/ejo/20.4.399.

4. Auger TA, Turley PK. The female soft tissue profile as presented in fashion magazines during the 1900s: a photographic analysis. Int J Adult Orthod Orthognath Surg 1999;14:7-18.

5. Spyropoulus MN, Halazonetis DJ. Significance of the soft tissue profile on facial esthetics. Am J Orthod Dentofacial Orthop 2001;119: 464-471. DOI: 10.1067/mod.2001.113656.

6. Zhu NW, Senewiratne $S$, et al. Lip posture and mouth width in children with unilateral cleft lip. Br J Plast Surg 1994;47:301-305. DOI: 10.1016/0007-1226(94)90086-8.

7. Bearn DR, Sandy JR, et al. Photogrammetric assessment of the soft tissue profile in unilateral cleft lip and palate. Cleft Palate Craniofac J 2002;39:597-602. DOI: 10.1597/1545-1569_2002_039_0597_ paotst_2.0.co_2.

8. Bittner C, Pancherz H. Facial morphology and malocclusions. Am J Orthod Dentofacial Orthop 1990;97:308-315. DOI: 10.1016/08895406(90)70103-J.

9. Ferrario VF, Sforza C, et al. Craniofacial morphometry by photographic evaluations. Am J Orthod Dentofacial Orthop 1993;103:327-337. DOI: 10.1016/0889-5406(93)70013-E. 
10. Fernandez-Riveiro P, Smyth-Chamosa E, et al. Angular photogrammetric analysis of the soft tissue facial profile. Eur J Orthod 2003;25:393-399. DOI: 10.1093/ejo/25.4.393.

11. Lai J, Ghosh J, et al. Effects of orthodontic therapy on the facial profile in long and short vertical facial patterns. Am J Orthod Dentofacial Orthop 2000;118:505. DOI: 10.1067/mod.2000.110331.

12. Dalci K, Steiner S. Soft tissue profiles of 3-5 years old pre-school children. J Clin Paed Dent 2011;35(3):339-344. DOI: 10.17796/ jcpd.35.3.d06q3q000n147568.

13. Bishara $\mathrm{SE}$, Peterson $\mathrm{LC}$, et al. Changes in facial dimensions and relationships between the ages of 5 and 25 years. Am J Orthod 1984;3:238-252.

14. Nanda RS, Meng $\mathrm{H}_{\text {, et }}$ al. Growth changes in the soft tissue facial profile. Angle Orthod 1990;60:177-190. DOI: 10.1043/0003-3219(1990)060<0177:GCITST>2.0.CO;2.
15. El-Batouti A, Ogaard B, et al. Longitudinal cephalometric standards for Norwegians between the ages of 6 and 18 years. Eur J Orthod 1994;16:501-509.

16. Prahl-Andersen B, Ligthelm-Bakker ASWMR, et al. Adolescent growth changes in soft tissue profile. Am J Orthod Dentofacial Orthop 1995; 107:476.

17. Dimaggio FR, Dellavia C, et al. Two vs three dimensional non-invasive analysis of facial soft tissues in 6-year old children. Eur J Orthod 2002;24:426.

18. Lundström F, Lundström A. Natural head position as a basis for cephalometric analysis. Am J Orthod Dentofacial Orthop 1992 Mar;101(3):244-247. DOI: 10.1016/0889-5406(92)70093-P.

19. Björk A, Krebs A, et al. A method for epidemiological registration of malocclusion. Acta Odontol Scand 1964;22:27-41. 